\section{ASSESSMENT OF RADIO TELECOMMUNICATION COVERAGE SIGNAL USING GEOSPATIAL ANALYSIS}

Mohd Sharul Aikal Baharima, Nor Hazmin Sabrib, Roslan Umarc*, Ainon Nisa Othmana, Siti Nur Dianah Abdul Rahmanb

aCentre of Studies Surveying Science and Geomatics, Faculty of Architecture, Planning \& Surveying Universiti Teknologi MARA, 40450, Shah Alam Selangor, Malaysia

bFaculty of Science and Marine Environment, Universiti Malaysia Terengganu, 21030 Kuala Nerus, Terengganu, Malaysia

cEast Coast Environmental Research Institute (ESERI), Universiti Sultan Zainal Abidin, Gong Badak Campus, 21300, Kuala Terengganu, Terengganu, Malaysia
Article history

Received

29 June 2021

Received in revised form

16 November 2021

Accepted

28 November 2021

Published Online

21 February 2022

*Corresponding author roslan@unisza.edu.my

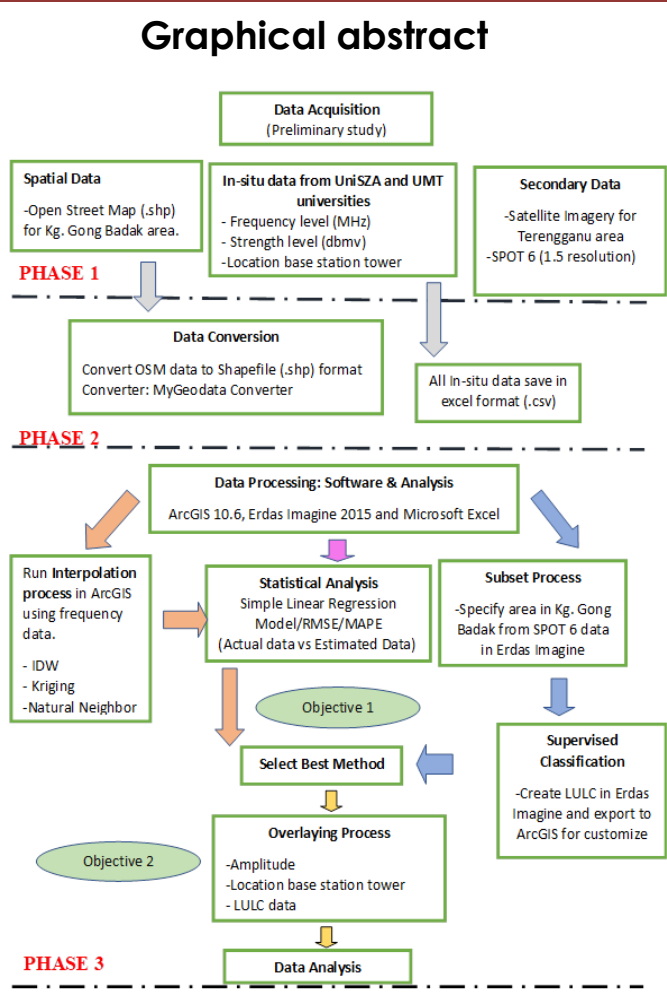

\begin{abstract}
With the advancement in Information and Communications Technology (ICT), the importance of telecommunication sectors is irrefutable. Rapid growth in this sector requires a good network coverage so the application of the technology is accessible for all purpose from everywhere. In this study, the radio telecommunication coverage signal in $\mathrm{Kg}$. Gong Badak, Universiti Malaysia Terengganu (UMT) and Universiti Sultan Zainal Abidin (UNISZA) have analysed to estimate the frequency $(\mathrm{MHz})$ level using different interpolation techniques (IDW, Natural Neighbor, and Kriging) to select the best method. Then, the relationship between signal strength level (amplitude) and Land Use Land Cover (LULC) data was identified. Several statistical approaches such as Linear Regression Model and Rank Spearman Correlation Coefficient were implemented in this study. From the findings, we found that the Kriging method is the best technique to be applied for network coverage assessment. We also found that the relationship between signal strength (amplitude) and LULC in $\mathrm{Kg}$. Gong Badak exists either in environmental aspects or physical structures. Kg.Tok Jembal, UMT, Kg. Pak Tuyu and Kg. Jati show a strong positive linear relationship ( $\mathrm{p}$-value of $<1 \%$ ) between signal strength received and a 100-meter interval for 1 kilometer from the base station tower (BST). This indicates that the distance from the BST determines the signal strength. This study can be beneficial for the government and the players in the telecommunication industry to monitor the network coverage in Malaysia to provide a better service.

Keywords: Radio Telecommunication, Frequency, Geospatial, Signal, Interpolation
\end{abstract}

\title{
Abstrak
}

Dengan kemajuan dalam teknologi maklumat dan komunikasi (ICT), kepentingan sector telekomunikasi tidak dapat disangkal lagi. Pertumbuhan rancak dalam sektor ini memerlukan liputan jaringan agar 
aplikasi teknologi ini dapat dicapai untuk pelbagai tujuan dari manamana sahaja. Dalam kajian ini, liputan isyarat telekomunikasi radio di $\mathrm{Kg}$. Gong Badak, Universiti Malaysia Terengganu (UMT) dan Universiti Sultan Zainal Abidin (UNISZA) telah dianalisis untuk mengukur aras frekuensi (MHz) menggunakan teknik interpolasi berbeza (IDW, Natural Neighbor, and Kriging) bagi menentukan kaedah terbaik. Kemudian, hubungan antara aras kekuatan signal (amplitud) dengan data guna tanah dan litupan bumi (LULC) dikenalpasti. Beberapa pendekatan statistik seperti model regresi linear dan pekali darjah korelasi Spearman juga dilakukan dalam kajian ini. Daripada hasil kajian, didapati kaedah Kriging adalah teknik yang terbaik digunakan dalam penilaian liputan jaringan. Kami juga dapati wujud hubungan antara kekuatan signal (amplitud) dengan LULC di $\mathrm{Kg}$. Gong Badak sama ada dalam aspek alam sekitar atau struktur fizikal. Kg.Tok Jembal, UMT, Kg. Pak Tuyu and $\mathrm{Kg}$. Jati menunjukkan hubungan linear positif yang kuat ( $\mathrm{p}$-value $<1 \%$ ) antara kekuatan signal yang diterima dengan sela jarak 100-meter bagi 1 kilometer dari Menara telekomunikasi (BST). Ini menunjukkan jarak dari BST memainkan peranan dalam penentuan kekuatan signal. Kajian ini bermanfaat untuk pihak kerajaan dan pemain industri telekomunikasi bagi memantau liputan jaringan di Malaysia agar perkhidmatan yang lebih baik dapat disediakan.

Kata kunci: Radio Telekomunikasi; Frekuensi; Geospatial; Signal; Interpolasi

(C) 2022 Penerbit UTM Press. All rights reserved

\subsection{INTRODUCTION}

The Malaysian wireless telecommunication industry has gone through excessive changes resulting in some domination, expansion, and consolidation in telecommunication coverage. Statistically, the wireless telecommunication sector in Malaysia has witnessed tremendous growth in the number of subscribers. According to Malaysian Communications \& Multimedia Commission (MCMC) in 2018 annual report , there were an estimated 9.05 million subscribers in total, or a $36.9 \%$ penetration rate per 100 inhabitants in 2002. This figure has risen drastically to approximately 41.33 million subscribers, equivalent to a $142.5 \%$ penetration rate per 100 inhabitants by 2012 [1]. It is clearly been seen the increased consumption in telecommunication services and the society is slowly accepting and adapting the technology.

Nowadays, this kind of online technology and its application is a compulsory as an interaction medium between people and the government office as well as business-related matters. According to Lim et al. (2021), smart city development has been gaining global momentum and many countries have developed their own blueprints including Malaysia [2]. The Malaysian Smart City Framework (MSCF) indicates that the government is paying full attention to consider the implementation of smart city governance [3].

Furthermore, in this COVID-19 pandemic era where we need to reduce the physical contact, this ICT technology implementation is a must as an alternative. This situation has demanded a good network coverage for better experience to administer official matters and carry out daily activities. In the education industry, this need has been highlighted as various complaints have emerged from parents, lecturers, and students on how the poor coverage signals have caused difficulties for them to conduct the classes and organize teaching and learning activities [4], [5]. Therefore, this study aims to analyse the status of radio coverage signals with geospatial analysis using different methods of interpolation (IDW, Kriging, and Natural Neighbor), and investigate the relationship between signal strength level (amplitude) and Land Use Land Cover (LULC) to to get a general picture and basic description of internet network access at selected area. This can help stakeholders to assess and analyze the requirements for the sake of the establishment of a smart city.

\subsection{METHODOLOGY}

The study was conducted in Kg. Gong Badak, Terengganu, situated in Peninsula Malaysia. The coordinates of the exact location is at latitude and longitude of $5.407467^{\circ}$ and $103.083805^{\circ}$, respectively. On top of that, Terengganu has a significant amount of rainfall, around $2498 \mathrm{~mm}$ each year, and an average temperature of $26.1^{\circ} \mathrm{C}$. The selection of this area has been considered because of public concern regarding the status of coverage signals and the availability of data support. Figure 1 shows the study area in Kg. Gong Badak for radio telecommunication coverage signal. 


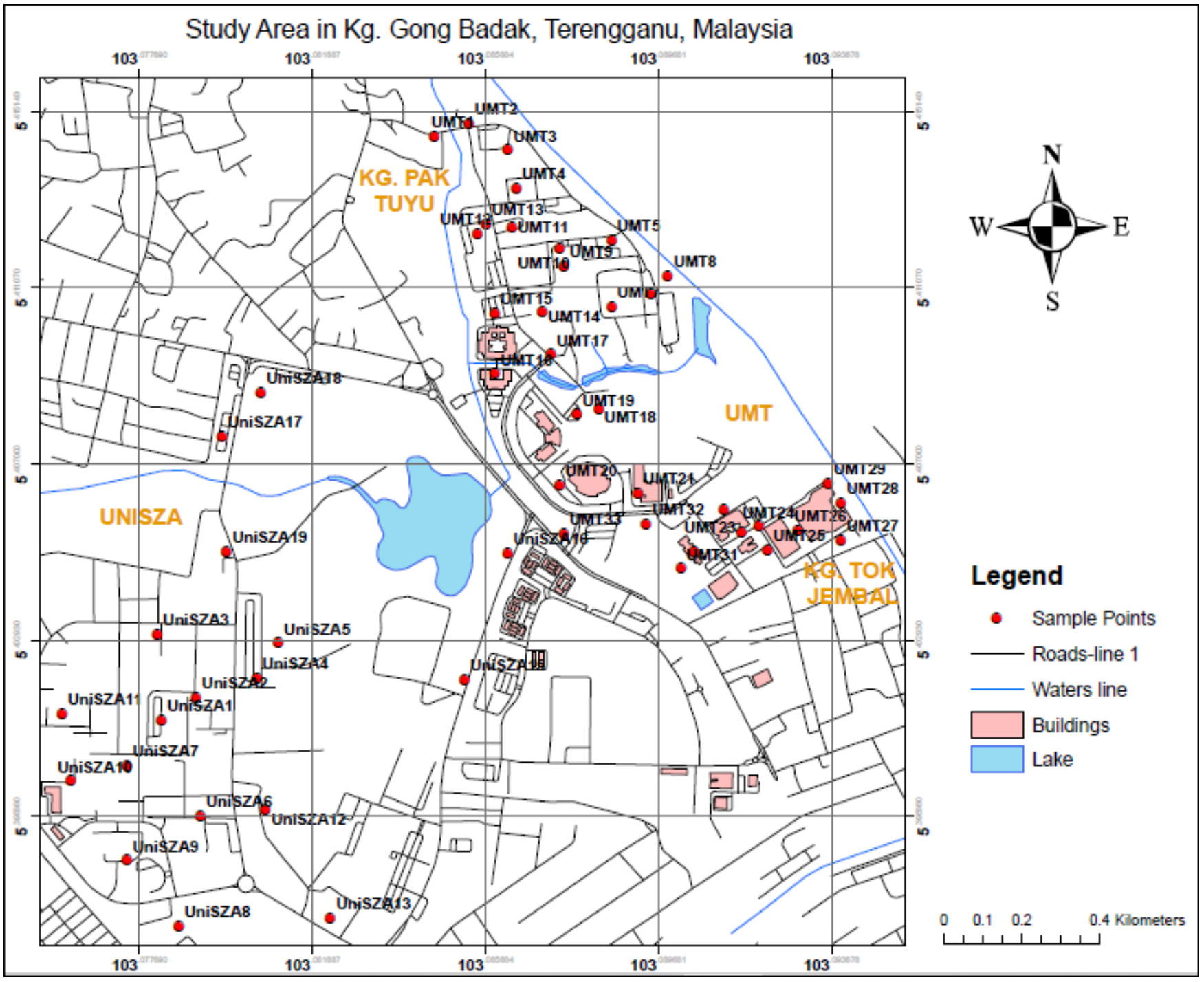

Figure 1 Map of study area in Kg. Gong Badak

\subsection{In-Situ Data from UNISZA and UMT Universities}

In-situ data or ground truth data refers to the data collection and sample needed for further analysis in any research conducted in actual inspection onground field. In this study, the data was fully provided by the research team in Universiti Sultan Zainal Abidin (UniSZA) and Universiti Malaysia Terengganu (UMT). The data consists of signal strength (amplitude) and the frequency level for the telecommunication in Kampung (Kg.) Gong Badak. The process for collecting the data required a 10-minutes interval for each data point. Data collection was extracted by using a spectrum analyzer which provides both variables (frequency \& amplitude) for each point. The data observation was conducted in early November until the end of December 2017, and the frequency and amplitude range level did not change much for the next couple years [6].

\subsection{Spatial Data Extraction}

The spatial data that has been extracted in this study was a feature from buildings and water bodies: lakes, water lines, and roads. Every feature consists of detailed attributes for each of them. In this process, the spatial data has been extracted freely from the Open Street Map website. In the process of data extraction, the specific type of data to be used and the coverage for the area of interest was performed. Meanwhile, the satellite images data has been fully provided by Institute of Climate Change, Universiti Kebangsaan Malaysia (UKM) with 1.5 resolution from SPOT 6 satellite imagery.

\subsection{Variation Interpolation Techniques}

To estimate the unknown point of frequency data in $\mathrm{Kg}$. Gong Badak, various interpolation methods were performed, including Inverse Distance Weightage (IDW), Kriging, and Natural Neighbor. The formula of 
(1) IDW, (2) Kriging, and (3) Natural Neighbor is as follows:

$$
\hat{Z}\left(S_{0}\right)=\sum_{i=1}^{N} \lambda i z(S i),
$$

where $\mathrm{Z}\left(\mathrm{S}_{i}\right)$ is a measured value in location at the $i$ th location; $\lambda_{i}$ : unknown weight for measured value of $i$ th location; So: prediction of location; and $N$ : the number of measured values. The weighting $\lambda_{i}$ in IDW is primarily determined by the distance to the projection site, while in the Kriging process, the overall spatial arrangement of the measured points as well as the distance between the measured points and the prediction position are strongly dependent. Kriging and IDW techniques have been used in several areas, including mineral source prediction and astronomical purposes [7] [8].The Natural Neighbor method was applied based on the equal distance from the interpolation point, giving similar weights to the northernmost and northeastern points.

$$
V\left(\mathrm{n}_{1}\right)=\left\{\mathrm{x} \in \mathbb{R}^{\mathrm{d}}: d\left(\mathrm{x}, \mathrm{x}_{\mathrm{l}}\right)<\mathrm{d}\left(\mathrm{x}, \mathrm{x}_{\mathrm{J}}\right) \forall J \neq I\right\},
$$

where $V(n)$ is the first order of Voronoi cell for a node $\mathrm{n}_{1}$ within the convex hull is a convex polygon (polyhedron) in $\mathbb{R}^{2}\left(\mathbb{R}^{3}\right)$; and $d\left(x, x_{1}\right)$ is the appropriate Euclidean distance function [9]. This method is widely used for water management and elevation estimation [10], [11].

\subsection{Supervised Classification and Overlaying Process}

Supervised classification is one of the crucial processes in this research to achieve Objective 2. The classification process was created by introducing few-layer classes in this research study, which includes beach breakwater, building structure, waterbodies, bareland, vegetation, and road classes. Each feature has been individually selected for 10 signature classes for each of them before being merged into 1 final individual class through Erdas Imagine software. The process has been run by performing the Maximum Likelihood algorithm as parametric rule setting and the result obtained from it being compared with Google Earth Pro image that have been linked to Erdas Imagine software for accuracy assessment analysis. The accuracy assessment being performed through exporting 40 random features from image classified as Class points and getting the Google Earth Pro feature coordinates as Reference point. Finally, the class features and the reference value has being run for their overall classification accuracy with $78.67 \%$ accuracy. Meanwhile, the overlaying process involved the results from the satellite image that has completed classification with few classes, the vector dataset from signal strength (amplitude) data, and the location of the base station tower in $\mathrm{Kg}$. Gong Badak.

\subsection{Rank Spearman Correlation Coefficient Analysis}

In studying the relationship between the two variables, the signal strength and LULC data was analyzed. From the statistical aspect, Rank Spearman Correlation Coefficient analysis is not something new to support the various applications even to measure the mixing pattern for the complex network [12]. In fact, it can also be used for non-normally distributed continuous data for ordinal data or with data that have relevant outliers [13]. Since the data did not follow the normal distribution then the Spearman Rank Correlation analysis (non-parametric test) was used to test the strength of the linear relationship between two variables. The formula of rank spearman correlation coefficient (4) is as shown below [14],[15]:

$$
\mathrm{rs}=1-\left(6 \sum d i^{2}\right) / \mathrm{n}\left(\mathrm{n}^{2}-1\right)
$$

where $r_{s}$ is the value of rank spearman correlation; di is the difference between 2 ranks measured; and $n$ is the number of observations. To interpret the results, the spearman correlation coefficient, $r_{s}$, can be somewhere between +1 and -1 . $A r_{s}$ of +1 indicates $a$ perfect positive rank association, $a r_{s}$ of zero indicates no rank association, and a $r_{s}$ of -1 indicates a perfect negative rank association. The lower the relationship between the ranks, the nearer $r_{s}$ is to 0 .

\subsection{RESULTS AND DISCUSSION}

This section elaborates the estimation results of the frequency level from different interpolation methods (IDW, Natural Neighbor, and Kriging). In addition, statistical analysis using linear regression model and rank spearman correlation method are also discussed in this section. Subsequently, the relationship between strength level (amplitude) with Land Use Land Cover (LULC) will be discussed. To support this objective, the existence of the base station tower (BST) will also be included. 
Table $1 \mathrm{In}$-situ data for frequency level and estimated value from interpolation techniques

\begin{tabular}{|c|c|c|c|c|c|c|c|}
\hline $\begin{array}{l}\text { SAMPLE } \\
\text { POINTS }\end{array}$ & $\begin{array}{l}\text { LATITUDE } \\
\left(^{\circ}\right)\end{array}$ & $\begin{array}{c}\text { LONGITUDE } \\
\left({ }^{\circ}\right)\end{array}$ & $\begin{array}{l}\text { HIGHEST PEAK } \\
\text { (dBmv) }\end{array}$ & $\begin{array}{l}\text { FREQUENCY F } \\
\quad(\mathrm{MHz})\end{array}$ & IDW & KRIGING & $\begin{array}{c}\text { NATURAL } \\
\text { NEIGHBOR }\end{array}$ \\
\hline UNISZA1 & 5.401086 & 103.0782 & -90.85150462 & 75 & 88 & 92 & 71 \\
\hline UNISZA2 & 5.401589 & 103.079 & -78.77949212 & 90 & 117 & 108 & 96 \\
\hline UNISZA3 & 5.403064 & 103.0781 & -78.61574676 & 70 & 123 & 77 & 113 \\
\hline UNISZA4 & 5.402056 & 103.0804 & -77.08706002 & 82 & 140 & 86 & 140 \\
\hline UNISZA5 & 5.402856 & 103.0809 & -71.74681574 & 112 & 159 & 124 & 158 \\
\hline UNISZA6 & 5.398881 & 103.0791 & -73.2742547 & 150 & 190 & 154 & 184 \\
\hline UNISZA7 & 5.400025 & 103.0774 & -87.2539752 & 203 & 197 & 190 & 201 \\
\hline UNISZA8 & 5.396336 & 103.0786 & -75.56917566 & 225 & 227 & 238 & 242 \\
\hline UNISZA9 & 5.397836 & 103.0774 & -83.91568446 & 248 & 233 & 246 & 239 \\
\hline UNISZA 10 & 5.399672 & 103.0761 & -71.29813956 & 270 & 240 & 260 & 256 \\
\hline UNISZA 11 & 5.401247 & 103.0759 & -71.10269029 & 293 & 248 & 265 & 266 \\
\hline UNISZA12 & 5.399003 & 103.0806 & -67.37100063 & 315 & 279 & 314 & 317 \\
\hline UNISZA 13 & 5.396517 & 103.0821 & -75.76825076 & 338 & 330 & 353 & 341 \\
\hline UNISZA 14 & 5.395769 & 103.0829 & -80.34307314 & 360 & 346 & 359 & 366 \\
\hline UNISZA 15 & 5.402003 & 103.0852 & -83.23605615 & 1120 & 420 & 1114 & 441 \\
\hline UNISZA 16 & 5.404944 & 103.0862 & -72.79196795 & 850 & 444 & 847 & 687 \\
\hline UNISZA17 & 5.407631 & 103.0796 & -70.93980108 & 428 & 426 & 436 & 443 \\
\hline UNISZA 18 & 5.408633 & 103.0805 & -71.4891052 & 450 & 444 & 457 & 433 \\
\hline UNISZA19 & 5.404975 & 103.0797 & -85.82420572 & 473 & 448 & 469 & 452 \\
\hline UMT1 & 5.414542 & 103.0845 & -68.82425509 & 68 & 76 & 108 & 94 \\
\hline UMT2 & 5.41485 & 103.0853 & -66.43733922 & 90 & 95 & 91 & 90 \\
\hline UMT3 & 5.414247 & 103.0862 & -91.31579943 & 113 & 123 & 117 & 118 \\
\hline UMT4 & 5.413367 & 103.0864 & -129.103677 & 135 & 171 & 154 & 147 \\
\hline UMT5 & 5.412167 & 103.0886 & -90.47159645 & 158 & 167 & 163 & 192 \\
\hline UMT6 & 5.410928 & 103.0895 & -88.17282724 & 180 & 190 & 192 & 238 \\
\hline UMT7 & 5.410644 & 103.0886 & -100.2214758 & 203 & 215 & 204 & 206 \\
\hline UMT8 & 5.411339 & 103.0899 & -91.12819741 & 225 & 221 & 224 & 285 \\
\hline UMT9 & 5.411575 & 103.0875 & -88.69670088 & 248 & 253 & 232 & 270 \\
\hline UMT10 & 5.411956 & 103.0874 & -77.04681426 & 270 & 259 & 274 & 276 \\
\hline UMT11 & 5.412469 & 103.0863 & -92.23698195 & 293 & 281 & 295 & 315 \\
\hline UMT12 & 5.412322 & 103.0855 & -80.5356964 & 315 & 309 & 324 & 320 \\
\hline UMT13 & 5.412539 & 103.0857 & -96.06286617 & 338 & 314 & 307 & 277 \\
\hline UMT14 & 5.410514 & 103.087 & -97.04029053 & 360 & 342 & 338 & 380 \\
\hline UMT15 & 5.410486 & 103.0859 & -84.45140813 & 383 & 158 & 376 & 376 \\
\hline UMT16 & 5.409072 & 103.0859 & -86.05848978 & 405 & 402 & 418 & 414 \\
\hline UMT17 & 5.409519 & 103.0872 & -82.95052323 & 428 & 393 & 406 & 401 \\
\hline UMT18 & 5.408272 & 103.0883 & -84.33950269 & 450 & 487 & 439 & 410 \\
\hline UMT19 & 5.408142 & 103.0878 & -78.67885021 & 473 & 488 & 431 & 459 \\
\hline UMT20 & 5.4065 & 103.0874 & -74.33005293 & 495 & 547 & 732 & 491 \\
\hline UMT21 & 5.406328 & 103.0892 & -73.76656281 & 2354 & 543 & 2152 & 1421 \\
\hline UMT22 & 5.405944 & 103.0912 & -71.46356602 & 2352 & 558 & 2390 & 1165 \\
\hline UMT23 & 5.405417 & 103.0916 & -75.59298491 & 2400 & 615 & 2450 & 1196 \\
\hline UMT24 & 5.405556 & 103.092 & -79.78608184 & 2500 & 783 & 2532 & 1232 \\
\hline UMT25 & 5.405 & 103.0922 & -75.51619878 & 1327 & 1203 & 1429 & 1147 \\
\hline UMT26 & 5.405472 & 103.0929 & -73.45766231 & 2560 & 872 & 2455 & 1377 \\
\hline UMT27 & 5.40525 & 103.0939 & -65.19691106 & 2300 & 832 & 2200 & 1021 \\
\hline UMT28 & 5.406081 & 103.0939 & -60.31460723 & 2365 & 1451 & 2378 & 2216 \\
\hline UMT29 & 5.406542 & 103.0936 & -66.4216516 & 2200 & 2391 & 2247 & 2424 \\
\hline UMT30 & 5.404983 & 103.0905 & -78.5544949 & 2236 & 722 & 2177 & 1073 \\
\hline UMT31 & 5.404578 & 103.0902 & -62.22677357 & 1420 & 510 & 1436 & 1233 \\
\hline UMT32 & 5.405603 & 103.0894 & -64.79870307 & 2050 & 1925 & 2044 & 1879 \\
\hline UMT33 & 5.405378 & 103.0875 & -64.34301475 & 1501 & 1436 & 1362 & 1273 \\
\hline
\end{tabular}




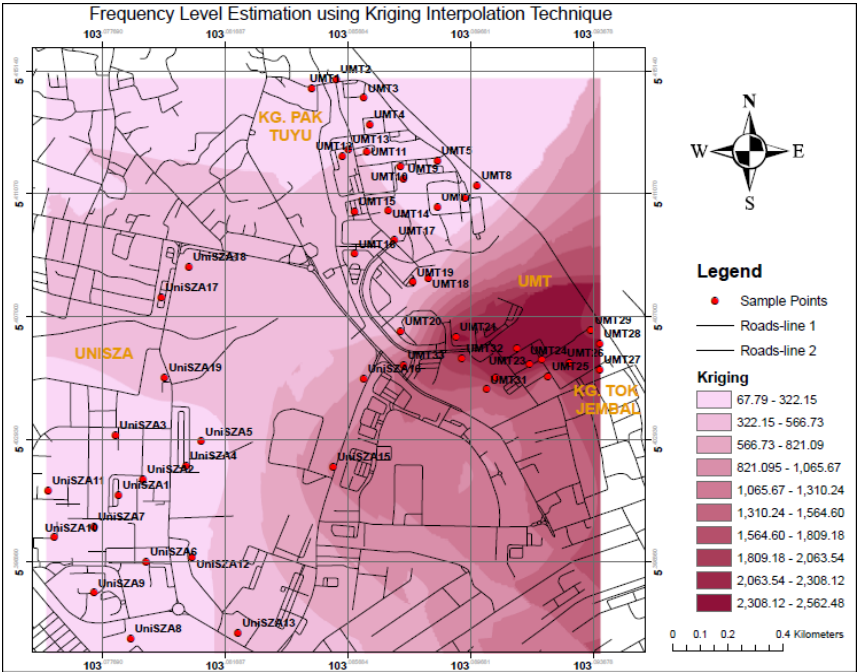

(a)

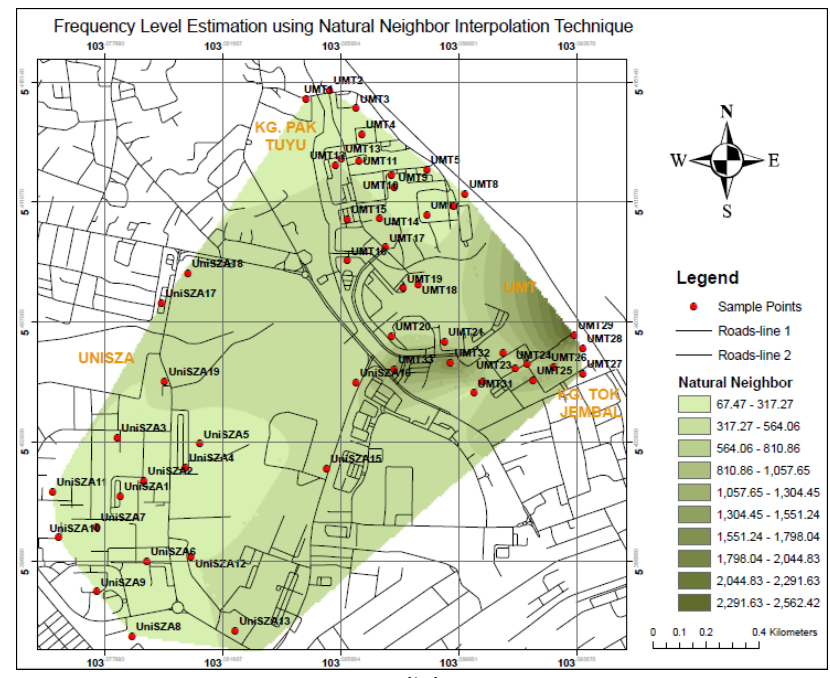

(b)

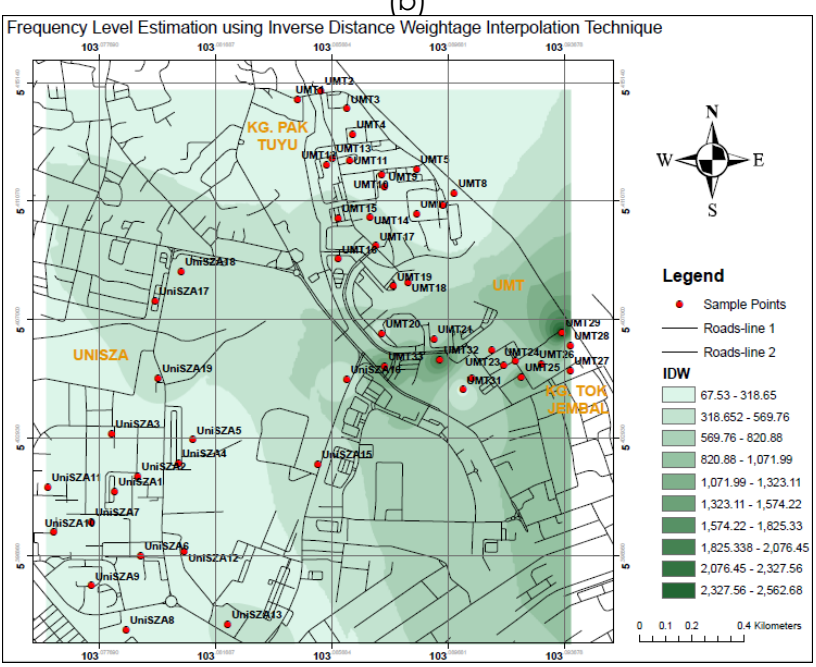

(c)

Figure 2 Interpolation process in (a) IDW, (b) Natural Neighbor, and (c) Kriging method

\subsection{Estimation Frequency ( $\mathrm{MHz})$ from Multiple Interpolation Methods}

The map produced from frequency coverage in the $\mathrm{Kg}$. Gong Badak area is shown in Figure 2. This shows the results after interpolation was being produced for different techniques in the same sample point data. The results of interpolation were classified into 10 classification levels for all techniques to avoid biases in the results obtained. In Figure 2(c), the Kriging technique was applied, which shows the range of data started from a lower to higher frequency 167 $\mathrm{MHz}-2562 \mathrm{MHz}$ ) in the map legend. Approximately, the range for these methods are the same as they followed the same data input. In the context of the hot-spot area, the result is a map highlighting a strong hot-spot frequency area (darker area) on the right side of the map along with the opposite side(brighter area) for low-frequency level.

Figure 2(b) shows a different result when the Natural Neighbor method was used for interpolation. The results show that the higher-level frequency (darker area) highlighted two extra areas on the right side of the map, providing the same result for the low-frequency level view as the Kriging method in the opposite side (brighter area). However, the main difference between the Natural Neighbor method with other techniques is that the method does not apply distance as a weight but creates Delauney Triangulation and selects the nearest cell value and uses the proportional of the area as weight instead [16]. This is the nature of the Natural Neighbor technique. Lastly, Figure 2(c) revealed the results for the Inverse Distance Weightage (IDW) interpolation method from the sample data. The variation of this interpolation result does not differ much compared to the Natural Neighbor technique as it highlights the same hot-spot frequency (darker area) and lower frequency for the opposite side (brighter area). The coverage remains the same with the Kriging technique, which covers a large area without any specific settings in the ArcGIS software. To support the analysis regarding the actual values from the frequencies obtained with the estimation from different techniques (IDW, Natural Neighbor, and Kriging), a statistical analysis has been used to support the image produced. The correlation between actual and estimated data for frequency was revealed by using the Simple Linear Regression method. Figure 3 displays the results for the following methods: (a) IDW, (b) Natural Neighbor, and (c) Kriging. 


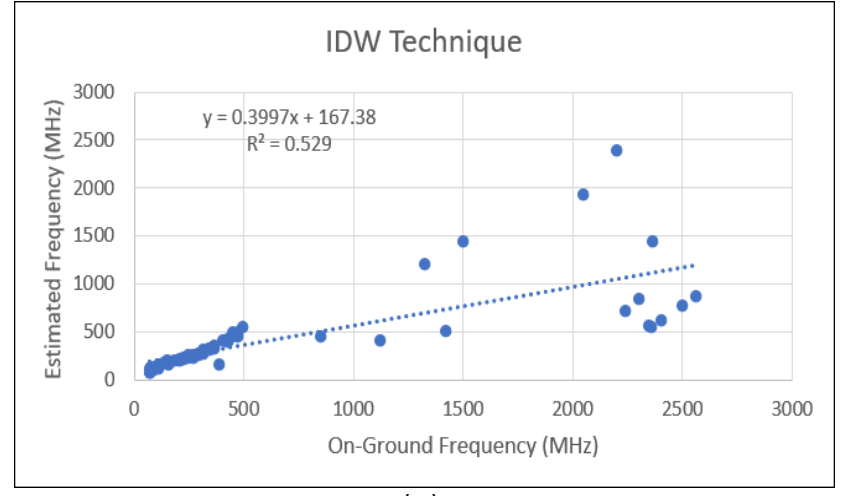

(a)

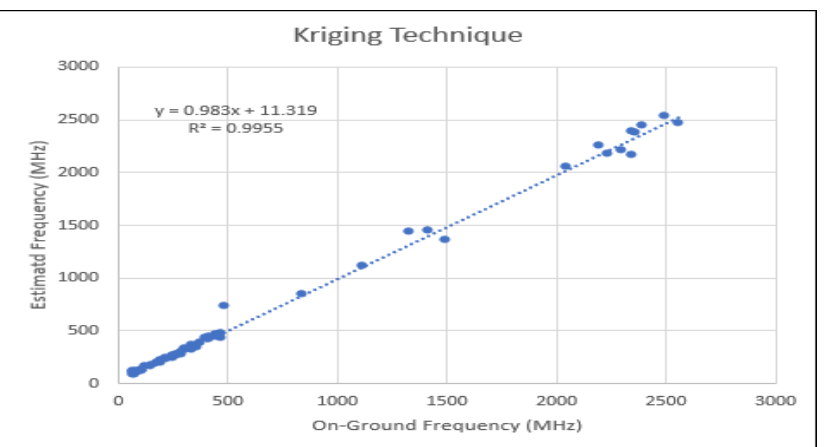

(c)

Figure 3 Linear regression for (a) IDW, (b) Natural Neighbor, and (c) Kriging methods

Figure 3(a) shows the results for the linear regression model for Inverse Distance Weightage (IDW) with actual data on-ground. The regression equation of $y=0.3997 x+167.38$ and $r^{2}=0.529$ show $a$ moderate positive relationship between these variables. The results show that the IDW method has the lowest correlation among the three methods. In terms of the Root Mean Square Error (RMSE) and Mean Absolute Percentage Error (MAPE) results in Table 2, this method has the highest value among all methods, which are 17.19 and 5.97, respectively. As a rule of thumb, the lower the RMSE value, the more reliable the results of the comparison. Figure 3(b) shows the results for the linear regression model between the Natural Neighbor method with actual data on-ground. The regression equation of $y=$ $0.6005 x+119.87$ and $r^{2}=0.8135$ indicated a strong positive relationship estimation by using this method. Table 2 indicates that the RMSE and MAPE results for the Natural Neighbor method falls in second place among the three methods, which had values of 13.756 and 4.52 respectively. Finally, the results from Figure $3(c)$ shows a linear regression model for the Kriging method with actual data on-ground. The regression equation of $y=0.983 x+11.319$ and $r^{2}=$ 0.9955 generated for both data sets indicated a strong positive relationship between them. This

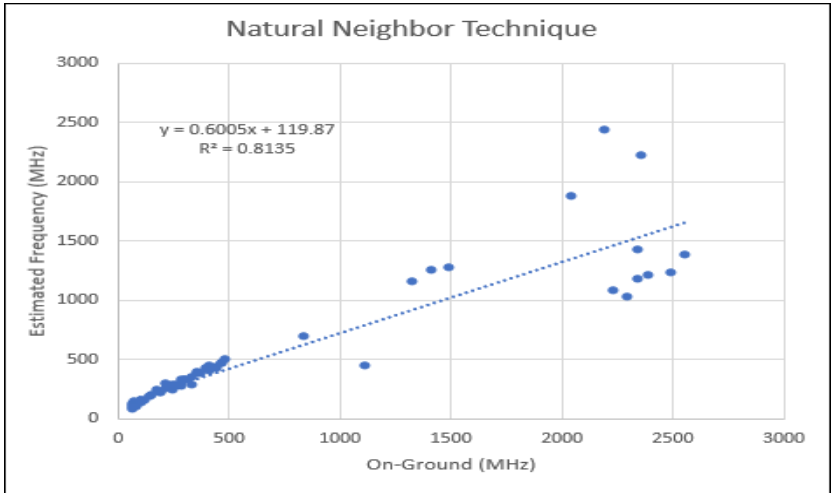

(b)

Table 2 Statistical Analysis Interpolator

\begin{tabular}{cccccc}
\hline Interpolator & $\begin{array}{c}\text { No. } \\
\text { of } \\
\text { Points } \\
\text { (N) }\end{array}$ & $\begin{array}{c}\text { Mean } \\
\text { Absolute } \\
\text { Deviation } \\
\text { (MAD) }\end{array}$ & $\begin{array}{c}\text { Mean } \\
\text { Square } \\
\text { Error } \\
\text { (MSE) }\end{array}$ & $\begin{array}{c}\text { Root } \\
\text { Mean } \\
\text { Square } \\
\text { Error } \\
\text { (RMSE) }\end{array}$ & $\begin{array}{c}\text { Mean } \\
\text { Absolute } \\
\text { Percentage } \\
\text { Error } \\
\text { (MAPE) }\end{array}$ \\
\hline Kriging & 52 & 2.481 & 39.712 & 6.302 & 1.87 \\
$\begin{array}{c}\text { Natural } \\
\text { Neighbor }\end{array}$ & 52 & 5.308 & 189.231 & 13.756 & \\
& & & & & \\
IDW & 52 & 7.154 & 295.500 & 17.19 & \\
& & & & & \\
\hline
\end{tabular}

method scored the best RMSE and MAPE values among the three methods, which are 6.302 and 1.87, respectively. To determine the best interpolation method in a radio telecommunication network, a few considerations can be considered based on the outcomes produced. Firstly, the selection of the method is highly dependent on the purpose of the project or research being conducted. Also, the nature of the feature knowledge is a vital part that needs to be understood. Other than that, the type of data sample with an appropriate sample size play a significant factor in selecting the method, either dynamic or physical data with a small or large sample [17]. Next, the variation of sample data has a big effect on the interpolation results. A welldistributed data sample can enhance the qualities of the data image being obtained. In this research, the data provided is limited but still, the variation distribution can be seen and be analyzed in detail for the estimation. Thirdly, the statistical support produced shows their reliability through the crossvalidation method. The result through the validation proses can be highly dependable and improve the accuracy of the results achieved. Overall, it can be justified that the Kriging method is the most suitable method in frequency coverage since the visualization results does not have too much 
exaggeration from the actual sample point as compared to the IDW method. This result is supported by [18] in their reviewed research when the presence of local extreme at data points for radio signal occur in the IDW technique, therefore the Kriging method is preferred instead. They also added how the Kriging method can minimize errors in prediction. Hence, it is being implemented by most of the other researchers in signal strength. Other than that, the linear regression model in Kriging also shows the highest reliability compared to the other methods $\left(\mathrm{r}^{2}=\right.$ 0.9955). The Natural Neighbor method is not the best method because of the limitation area in prediction since the nature of the method is based on the Thiessen Polygon concept for the process [16] and does not reveal the other estimation value for another side area (Figure 9(b)). Moreover, the linear regression model for the Natural Neighbor method $\left(r^{2}\right.$ $=0.8135)$ fell to second place after the Kriging method.

\subsection{Relationship between Signal Strength and Land Use Land Cover (LULC) features}

This section discusses the relationship between signal strength and Land Use Land Cover (LULC) with reference to the signal level in $\mathrm{Kg}$. Gong Badak. Figure 4 shows the distribution map for signal strength in $\mathrm{Kg}$. Gong Badak followed by Table 3, which shows a tabulated table between LULC and signal strength.
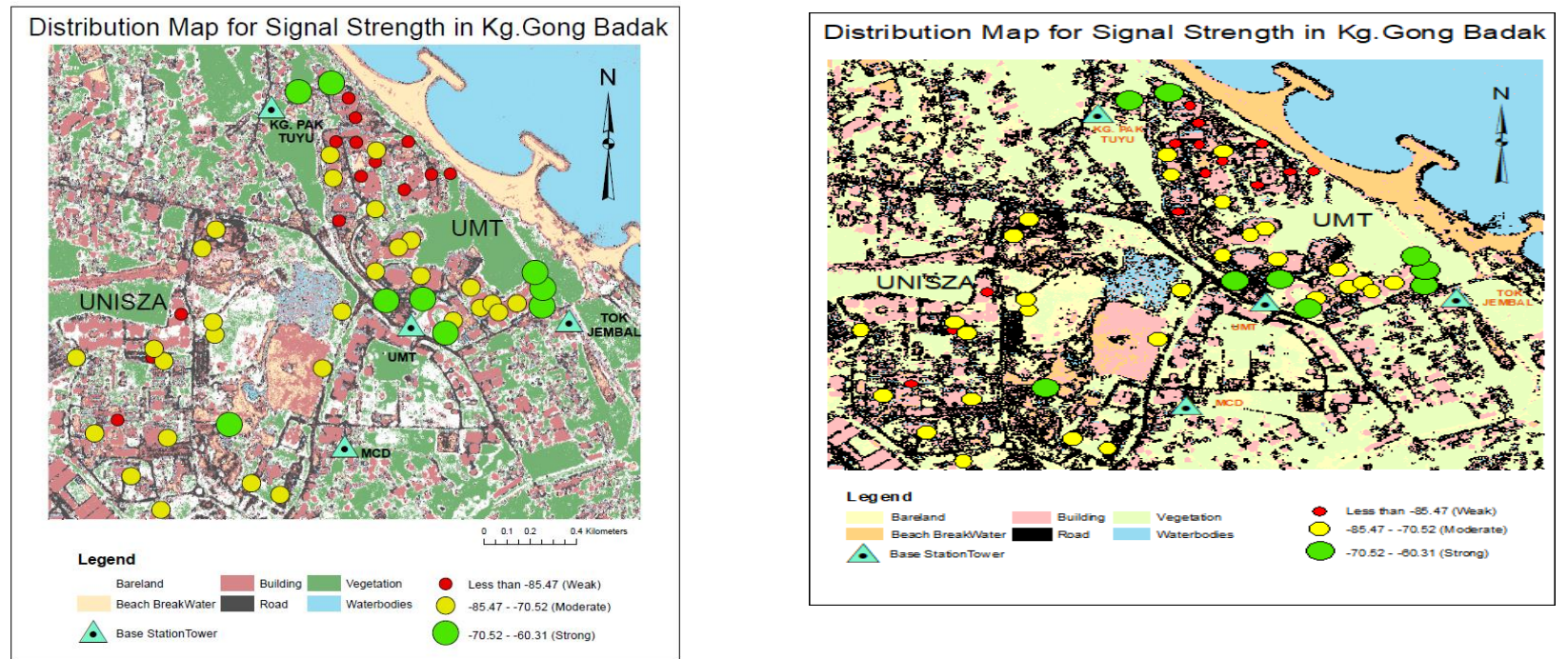

Figure 4 Signal strength map in Kg Gong Badak

Table 3 Signal strength and Land Use Land Cover (LULC) features

\begin{tabular}{ccc}
\hline $\begin{array}{c}\text { Land Use Land } \\
\text { Cover (LULC) } \\
\text { type }\end{array}$ & Signal Strength (dbmv) & $\begin{array}{c}\text { Class } \\
\text { level }\end{array}$ \\
\hline Bareland & & Moderate \\
Bareland & -83.916 & Moderate \\
Bareland & -72.792 & Moderate \\
Building & -80.343 & Weak \\
Building & -96.062 & Weak \\
Building & -100.221 & Moderate \\
Vegetation & -77.047 & Moderate \\
Vegetation & -82.951 & Strong \\
Vegetation & -64.798 & Moderate \\
Road & -73.457 & Moderate \\
Road & -77.047 & Moderate \\
Road & -82.951 & Moderate \\
Waterbodies & -83.236 & Moderate \\
Beach & -72.972 & - \\
Breakwater & - & \\
& &
\end{tabular}

The next objective in this research is to identify the relationship between signal strength level (Amplitude) and Land Use Land Cover (LULC) data. Figure 4 shows a map generated using a simple overlaying process between the signal strength $(\mathrm{dBmv})$ of the frequency and Land Use Land Cover (LULC) from the satellite image. The LULC consists of a few classes which are Bareland, Building Structure, Beach Breakwater, Road, and Waterbodies. This map also shows the strength level for the area with an extra point from the base station tower. Besides, Table 3 has been introduced to support the analysis between signal strength value and Land Use Land Cover (LULC) data. This situation is different from the Strong Classes level since the area of UMT shows an existing forest (Vegetation classes) which can be an obstacle due to the strong wind speeds from the beach. This hypothesis is supported by other research where they mentioned how the presence of forests able to reduce wind speeds significantly [19]. Secondly, the existence of the Weak Classes area consists of a lot of main buildings since the area is the center for students and administration in UMT. This aspect can be a significant factor for the weak strength level of the radio telecommunication signal. In facts, signal strength can be lost due to wall penetration from the building [20]. Other than that, other research also proven the finding with 
mentioned an average loss of signal strength of around $10.62 \mathrm{dBm}$ for concrete buildings and 4.25 $\mathrm{dBm}$ for block buildings [21]. Besides, network congestion during peak hours can cause users to experience lower signal strength than usual [22]. The findings explained how the effect 'cell breathing' process required the base station tower to decrease its coverage area so that the users can be offloaded to a neighboring tower. Since this area falls within the central movement for students and administration in UMT, this issue can be an added factor for the weak signal strength. Other than that, the distance between the base station tower (transmitter) and the point (receiver) can also affect the signal strength as mention by Syafiqah et. al[23]. Table 4 below shows the statistical results for Rank Spearman Correlation Coefficient analysis with signal strength from Class Level and Strength Value. The output for each base station tower is displayed along with the tab.

Table 4 Rank Spearman Correlation Coefficient analysis between signal strength from Class Level and Strength Value

\begin{tabular}{|c|c|c|c|c|}
\hline \multicolumn{5}{|c|}{ Base Station Tower: $\mathrm{Kg}$ Tok Jembal } \\
\hline $\begin{array}{l}\text { Class } \\
\text { Level }\end{array}$ & $\begin{array}{l}\text { Rank } \\
\text { Class } \\
\text { Level }\end{array}$ & $\begin{array}{c}\text { Strength } \\
\text { Value }\end{array}$ & $\begin{array}{c}\text { Rank } \\
\text { Strength }\end{array}$ & Output \\
\hline Strong & 9 & -65.1 & 9 & \multirow{10}{*}{$\begin{array}{c}\text { Coefficient } \\
\text { (rs) } \\
0.873863\end{array}$} \\
\hline Strong & 9 & -60.3 & 10 & \\
\hline Strong & 9 & -66.4 & 8 & \\
\hline Moderate & 4.5 & -76 & 5 & \\
\hline Moderate & 4.5 & -79 & 4 & \\
\hline Moderate & 4.5 & -74 & 7 & \\
\hline Moderate & 4.5 & -84.3 & 2 & \\
\hline Moderate & 4.5 & -74.3 & 6 & \\
\hline Moderate & 4.5 & -83 & 3 & \\
\hline Weak & 1 & -89 & 1 & \\
\hline \multicolumn{5}{|c|}{ Base Station Tower: UMT } \\
\hline $\begin{array}{l}\text { Class } \\
\text { Level }\end{array}$ & $\begin{array}{l}\text { Rank } \\
\text { Class } \\
\end{array}$ & Strength & $\begin{array}{c}\text { Rank } \\
\text { Strength }\end{array}$ & Output \\
\hline Strong & 10 & -64.3 & 10 & \multirow{2}{*}{$\begin{array}{c}\text { Coefficient } \\
\text { (rs) } \\
0.867467\end{array}$} \\
\hline Moderate & 6.5 & $\begin{array}{l}-79 \\
\end{array}$ & 8 & \\
\hline
\end{tabular}

Table 4 shows the result of the statistical analysis from the Rank Spearman Correlation Coefficient for the signal strength received with a 100-meter interval for 1 kilometer from the base station tower. In the map view from Figure 4, it shows 4 different locations where the base station towers exist, including UMT, MCD, Kg. Pak Tuyu, and Tok Jembal point in Kg. Gong Badak. The Rank Spearman Correlation Coefficient from the base station tower in Tok Jembal indicated a coefficient value of 0.873863 , with a $p$ value of 0.000474 . This result indicated a very strong

\begin{tabular}{|c|c|c|c|c|}
\hline Moderate & 6.5 & -79 & 8 & \multirow[b]{2}{*}{$\begin{array}{r}\text { t-statistic } \\
4.931839\end{array}$} \\
\hline Moderate & 6.5 & -80 & 6 & \\
\hline Moderate & 6.5 & -83 & 4 & \multirow{3}{*}{$\begin{array}{c}\text { Degree of } \\
\text { freedom } \\
8\end{array}$} \\
\hline Weak & 2 & -88.2 & 3 & \\
\hline Weak & 2 & -89 & 2 & \\
\hline Moderate & 6.5 & -81 & 5 & \multirow{3}{*}{$\begin{array}{l}\text { P-value } \\
0.000573\end{array}$} \\
\hline Moderate & 6.5 & -71.5 & 9 & \\
\hline Weak & 2 & -91.3 & 1 & \\
\hline \multicolumn{5}{|c|}{ Base Station Tower: MCD } \\
\hline $\begin{array}{l}\text { Class } \\
\text { Level }\end{array}$ & $\begin{array}{l}\text { Rank } \\
\text { Class }\end{array}$ & Strength & $\begin{array}{c}\text { Rank } \\
\text { Strength }\end{array}$ & Output \\
\hline Moderate & 6.5 & -83.2 & 5 & \multirow{10}{*}{$\begin{array}{c}\begin{array}{c}\text { Coefficient } \\
\text { (rs) }\end{array} \\
0.876523 \\
\\
\text { t-statistic } \\
5.15037 \\
\\
\text { Degree of } \\
\text { freedom } \\
8 \\
\\
\text { P-value } \\
0.000437\end{array}$} \\
\hline Moderate & 6.5 & -80.3 & 6 & \\
\hline Strong & 10 & -67.4 & 10 & \\
\hline Moderate & 6.5 & -73 & 9 & \\
\hline Moderate & 6.5 & -77.1 & 8 & \\
\hline Moderate & 6.5 & -79 & 7 & \\
\hline Weak & 2 & -86 & 2.5 & \\
\hline Moderate & 6.5 & -84.3 & 4 & \\
\hline Weak & 2 & -86 & 2.5 & \\
\hline Weak & 2 & -97 & 1 & \\
\hline \multicolumn{5}{|c|}{ Base Station Tower: Kg Pak Tuyu } \\
\hline $\begin{array}{l}\text { Class } \\
\text { Level }\end{array}$ & $\begin{array}{l}\text { Rank } \\
\text { Level }\end{array}$ & Strength & $\begin{array}{c}\text { Rank } \\
\text { Strength }\end{array}$ & Output \\
\hline Strong & 9.5 & -69 & 9 & \multirow{4}{*}{$\begin{array}{c}\text { Coefficient } \\
\text { (rs) } \\
0.939913 \\
\\
\text { t-statistic } \\
7.786628\end{array}$} \\
\hline Strong & 9.5 & -66.4 & 10 & \\
\hline Weak & 2.5 & -129.1 & 1 & \\
\hline Moderate & 6.5 & -84 & 5.5 & \\
\hline Weak & 2.5 & -89 & 3 & \multirow{6}{*}{$\begin{array}{c}\begin{array}{c}\text { Degree of } \\
\text { freedom } \\
8\end{array} \\
\text { P-value } \\
0.00002\end{array}$} \\
\hline Weak & 2.5 & -90.5 & 2 & \\
\hline Weak & 2.5 & -88.2 & 4 & \\
\hline Moderate & 6.5 & -84 & 5.5 & \\
\hline Moderate & 6.5 & -74 & 7.5 & \\
\hline Moderate & 6.5 & -74 & 7.5 & \\
\hline
\end{tabular}

relationship between the distance from the base station tower and signal strength with a $p$-value of < $1 \%$. As shown in Table 4, an indication of relationship strength guideline through the rs value is enough to conclude the result. Next, the statistical results for distance between base station towers in UMT, MCD and $\mathrm{Kg}$. Pak Tuyu from the data sample points indicated a coefficient value of 0.867467 with a $p$ value of $0.000573,0.876523$ with a $p$-value of 0.000437 , and 0.939913 with a p-value of 0.00002 , respectively. Overall, all of these show a strong 
positive linear relationship between them with a $\mathrm{p}$ value of $<1 \%$, which is close to the previous results in the base station tower at Tok Jembal. This confirms that the distance from the base station tower to the point receiver can be a factor for good signal strength in radio telecommunication. According to Syafiqah, exposure level at UMT and UniSZA have been invenced by telecommunication tower where as the network coverage is better to serve the denser populated area [23]. This result is also similar to the other research finding which also indicated that even the height of the base antenna influences the signal strength rather than only distance from base station tower [24]. However, the determination of the biggest factor for the weak signal strength in that area still cannot be justified concretely as there are other existing factors. The differences might be due to human factors such as measurement techniques, equipment used, location criteria and meteorology[[25]. Therefore, this concludes that the relationship between signal strength (amplitude) and LULC in Kg. Gong Badak exists either in environmental aspects or physical structures.

\subsection{CONCLUSION}

The role of wireless telecommunication and internet in our lives has become important, with more people spending more time doing daily things online than ever before. An increase in digitalization is leading firms and educational institutions to shift to work-fromhome (WFH) during COVID-19 pandemic [26]. This indicate that the network coverage improvement is essential and should be included in the government plan. Thus, this study is intended to analyze the radio telecommunication coverage signal in the vicinity of Kg. Gong Badak, Terengganu using three interpolation methods (Inverse Distance Weightage (IDW), Natural Neighbor and Kriging). From the result, we found that IDW is the best interpolator in estimating the frequency level of the signal. We also manage to identifythe relationship between signal strength level (amplitude) and Land Use Land Cover (LULC) and found a strong relationship exists between them which proved that the social activity and anthropogenic factor plays a role in determining the signal strength at the area. This research provide an insight on how GIS knowledge may contribute to the network coverage analysis.Moreover, this study shows the possible factors influencing the signal strength received in the area of interest. This knowledge can be beneficial for the government and the players in the telecommunication industry to provide good coverage signals for the people while considering factors influencing the signal strength. In future, more area with different type of land use should be analyzed for better understanding and to determine the influence of anthropogenic factors on the level of network coverage in Malaysia. Statistical analysis on residential exposure to radiofrequency in populated area such as mobile phone, base station and broadcast transmitter are suggested as well [27]

\section{Acknowledgement}

This study is made possible financially using the UMT internal grant, Talent and Publication Enhancement Research Grant (TAPE-RG, vot 55222). Special thanks to Universiti Teknologi MARA, Universiti Sultan Zainal Abidin, Universiti Kebangsaan Malaysia and Universiti Malaysia Terengganu for data, instruments and facilites provided. Baharim, M.S.A. personally acknowledged Yayasan Terengganu for the scholarship funding provided throughout his PhD study.

\section{References}

[1] Malaysian Communications \& Multimedia Commission. 2018. Industry Performance Report 2018 (pp. 1-170, Rep.) https://www.mcmc.gov.my/skmmgovmy/media/General /pdf/Industry-Performance-Report-2018.pdf.

[2] Lim, S. B., Malek, J. A., Yussoff, M. F. Y. M., Yigitcanlar, T. 2021. Understanding and Acceptance of Smart City Policies: Practitioners' Perspectives on the Malaysian Smart City Framework. Sustainability (Switzerland). 13(17): 9559.

[3] Department for International Trade. Ministry of Housing and Local Government, Malaysia. 2021. Malaysia Smart City Handbook https://www.kpkt.gov.my/kpkt/resources/user_l/GALERI/P DF_PENERBITAN/FRAMEWORK/Malaysia_Smart_City_Hand book_21062021_Final.pdf

[4] Ismail, N. S., Bakar, N. M., \& Wafa, S. W. 2020. Online Learning Challenges During Pandemic Covid-19 in Malaysian Higher Learning Institution. Universal Journal of Educational Research. 8(12): 7151-7159.

[5] Nassr, R. M., Aborujilah, A., Aldossary, D. A., \& Aldossary, A. A. 2020. Understanding Education Difficulty during COVID19 Lockdown: Reports on Malaysian University Students' Experience. IEEE Access. 8: 186939-186950.

[6] Malaysian Communications \& Multimedia Commission. 2020. Mobile Broadband Self-Declaration Report (pp. 1-23, Rep.). Peninsular Malaysia, Terengganu. doi:https://www.mcmc.gov.my/skmmgovmy/media/Gen eral/pdf/Self-Declaration-Report_Mobile-BB_MCMC_HI2020.pdf.

[7] Redzuan Tahar, M., Kamarudin, F., Umar, R., Khairul Amri Kamarudin, M., Hazmin Sabri, N., Ahmad, K., \& Sharul Aikal Baharim, M. 2017. Spatial Model of Sky Brightness Magnitude in Langkawi Island, Malaysia. Research in Astronomy and Astrophysics. 17(4): 037.

[8] Du, D., Yan, S., Yang, F., Zhu, Z., Song, Q., \& Yang, G. 2018. Kriging Interpolation for Evaluating the Mineral Resources of Cobalt-Rich Crusts on Magellan Seamounts. Minerals. 8(9): 374.

[9] Cueto, E., Sukumar, N., Calvo, B., Martínez, M. A Cegoñino, J., \& Doblaré, M. 2003. Overview And Recent Advances in Natural Neighbour Galerkin Methods. Archives of Computational Methods in Engineering, 10(4): 307-384.

[10] Curtarelli, M., Leão, J., Ogashawara, I., Lorenzzetti, J., \& Stech, J. 2015. Assessment of Spatial Interpolation Methods to Map the Bathymetry of an Amazonian Hydroelectric Reservoir to Aid in Decision Making for Water Management. ISPRS International Journal of GeoInformation. 4(1): 220-235.

[11] Setianto, A., \& Triandini, T. 2015. Comparison of Kriging and Inverse Distance Weighted (IDW) Interpolation Methods in 
Lineament Extraction and Analysis. Journal of Applied Geology. 5(1): 21-29.

[12] Zhang, W., Wei, Z., Wang, B., \& Han, X. 2016. Measuring Mixing Patterns in Complex Networks by Spearman Rank Correlation Coefficient. Physic A: Statistical Mechanics and Its Applications. 451: 440-450.

[13] Schober, P., Boer, C., \& Schwarte, L. A. 2018. Correlation Coefficients. Anesthesia \& Analgesia. 126(5): 1763-1768.

[14] Syed Zafar, S. N. A., Sabri, N. H., Umar, R., \& Ibrahim, Z. A. 2019. Radio Frequency Interference on Nearby Radio Astronomical Lines: Relationship between Wind Speed and Radio Signal Strength Measured at East Coast of Peninsular Malaysia. Sains Malaysiana. 48(1): 183-189. https://doi.org/10.17576/jsm-2019-4801-21.

[15] Shafie, M. M., Umar, R., \& Sabri, N. H. 2021. Statistical Analysis of Radio Frequency Interference (RFI) Caused by Solar Radiation During Wet and Dry. Malaysian Journal of Fundamental and Applied Sciences. 17(4): 430-436.

[16] Musashi, J. P., Pramoedyo, H., Fitriani, R. 2018. Comparison of Inverse Distance Weighted and Natural Neighbor Interpolation Method at Air Temperature Data in Malang Region. CAUCHY: Jurnal Matematika Murni dan Aplikasi. 5(2): 48.

[17] Lepot, M., Aubin, J.-B., \& Clemens, F. 2017. Interpolation in Time Series: An Introductive Overview of Existing Methods, Their Performance Criteria and Uncertainty Assessment. Water. 9(10): 796.

[18] Delmelle, E. M., Rogerson, P. A., Akella, M. R., Batta, R., Blatt, A., \& Wilson, G. 2005. A Spatial Model of Received Signal Strength Indicator Values for Automated Collision Notification Technology. Transportation Research Part C: Emerging Technologies. 13(5-6): 432-447.

[19] Quine, C., Coutts, M., Gardiner, B., \& Pyatss, G. 1995. Forests and Wind: Management to Minimise Damage (pp. 1-40) (United Kingdom, Forest Research). Surrey, UK: Forest Research Publications (CST).

[20] Elechi, P., \& Paul O. 2016. Investigation of GSM Signal Loss in Multi-Storey Building. Conference: International
Conference and Exhibition on ICT and Telecommunications At: Port Harcourt.

[21] Idim, A. I., \& Anyasi, F. I. 2014. Determination of Building Penetration Loss of Gsm Signals, Using Selected Buildings in Orhuwhorun, Delta State, Nigeria as a Case Study. IOSR Journal of Electronics and Communication Engineering. 9(5): 01-05.

[22] Network Guide 2014. Improving Mobile Signal (pp. 1-17, Rep.). Olson Ave, Australia: Powertec Telecommunications Pty. Doi:https://mobilenetworkguide.com.au/pdf/MobileNetwork-Guide-Improving-Mobile-Signal.pdf.

[23] Syafiqah, H. N., Hazmin, S. N., Umar, R., Dianah, A. R. S. N., Jaafar, H., Kamarudin, M. K. A., ... \& Ilyas, A. I. A. 2018. Non-ionizing Radiation: Exposure Level at UMT and UniSZA Campus. ASM Science Journal. 11: 183-194.

[24] Renke, A., \& Chavan, M. (2016). An Estimation of Electromagnetic Field Exposure from Cellular Mobile Base Station Towers in Densely Populated Residential Areas. Communications on Applied Electronics. 4(3): 5-9.

[25] Sabu, S., Renimol, S., Abhiram, D. \& Premlet, B. 2017. A Study on the Effect of Temperature on Cellular Signal Strength Quality. 2017. International Conference on Nextgen Electronic Technologies: Silicon to Software (ICNETS2).

[26] De', R., Pandey, N., \& Pal, A. 2020. Impact of Digital Surge during Covid-19 Pandemic: A Viewpoint on Research and Practice. International Journal of Information Management. 102171 https://doi.org/10.1016/j.ijinfomgt.2020.102171.

[27] Viel, J. F., Clerc, S., Barrera, C., Rymzhanova, R., Moissonnier, M., Hours, M., \& Cardis, E. 2009. Residential Exposure to Radiofrequency Fields from Mobile Phone Base Stations, and Broadcast Transmitters: A PopulationBased Survey with Personal Meter. Occupational and Environmental Medicine. 66(8): 550-556. 